\title{
WE THE EXCEPTIONAL AMERICAN PEOPLE
}

\author{
James E. Fleming* \\ [The People of America] reared the fabrics of governments \\ which have no model on the face of the globe.
}

The Federalist No. 141

\section{INTRODUCTION: "AMERICAN EXCEPTIONALISM"}

There is an academic movement afoot-one with a long historical pedigree-to attribute the vitality of the American constitutional order to "American exceptionalism." The most prominent representative of this school of thought is Bruce Ackerman, whose We the People opens with a jeremiad against the "Europeanization" of American constitutional theory and urges us as Americans to "look inward" to rediscover our distinctive patterns, practices, and ideals. $2 \mathrm{He}$ maps the terrain of theory as being divided into monists ("Anglophiles"), rights foundationalists ("Germanophiles"), and dualists (red-blooded Americans). ${ }^{3}$

* Associate Professor of Law, Fordham University. Ph.D. 1988, Princeton University; J.D. 1985, Harvard University; A.B. 1977, University of Missouri. I am grateful to Akhil Amar, Sot Barber, Debby Denno, Chris Eisgruber, John Finn, Martin Flaherty, Ned Foley, Samuel Freeman, Will Harris, Bob Kaczorowski, Greg Keating, Sandy Levinson, Steve Macedo, Linda McClain, Walter Murphy, John Rawls, Paul Schwartz, Tony Sebok, and Bill Treanor for helpful comments concerning this Article. I also would like to thank my research assistants Larry McCabe, Steven Shaw, and Sabrena Silver. Fordham University School of Law provided generous research support. I prepared an earlier version of this Article for the Georgetown University Law Center Discussion Group on Constitutional Law, December 4-5, 1993, which was organized by Mark Tushnet.

1. The Federalist No. 14, at 104 (James Madison) (Clinton Rossiter ed., New American Library, 1961).

2. Bruce Ackerman, We the People: Foundations 3-6, $32-33$ (Belknap Press, 1991) ("We the People").

3. Id. at 6-16, 32-33, 35-36. Monism emphasizes popular sovereignty over and against fundamental rights, and thus tends to equate popular sovereignty with parliamentary supremacy on a British model. Id. at 7-10, 35. Rights foundationalism challenges the primacy of popular sovereignty, stressing constraints imposed by deeper commitments to fundamental rights on a German model. Id. at 10-12, 35-36. Ackerman presents dualism as an "accommodation" between monism and rights foundationalism. Id. at 12-13. Dualism distinguishes between the constituent power of We the People, expressed in the higher law of the Constitution, and the ordinary power of officers of government, ex- 
Only dualists have the "strength" to declare our American independence from British and German models and philosophers.4 Thus, as Sanford Levinson observes, Ackerman is reopening the question about "American exceptionalism" from Europe.5

Ackerman published We the People in 1991, during the bicentennial celebration of the ratification of the Bill of Rights. Accordingly, it is tempting to dismiss his rhetoric of American exceptionalism as little more than patriotic flag-waving. But his argument that the American Constitution is dualist rather than rights foundationalist depends importantly upon a contrast that he draws between the American Constitution and the German Basic Law with respect to entrenchment of constitutional provisions against subsequent amendment. ${ }^{6}$ I shall assess this argu-

pressed in the ordinary law of legislation. Dualism preserves, against encroachment by ordinary law, the fundamental rights ordained and established by We the People in the higher law of the Constitution; to that extent, it is like rights foundationalism. But it preserves only those fundamental rights; beyond them, it is like monism in deferring to ordinary law. Id. at 12-13, 32-33.

There are problems with Ackerman's map of the terrain of American constitutional theory. For purposes of this Article, I shall put to one side the difficulties with his distinction between monism and dualism, and I shall accept his distinction between dualism and rights foundationalism. Elsewhere, I have suggested that one can be a dualist in a general sense without being committed to dualism in Ackerman's specific sense - that is, without endorsing his complex apparatus of higher lawmaking through structural amendments to the Constitution outside the formal Article $\mathrm{V}$ amending procedures, and without accepting his purported distinction between dualism and rights foundationalism on the ground that the former theory but not the latter rejects the idea that a duly ratified amendment might be unconstitutional. See James E. Fleming, Constructing the Substantive Constitution, 72 Tex. L. Rev. 211, 287 n.380, 290 n.405 (1993). Furthermore, I have outlined a constitutional constructivism, id. at 217-20, 280-304, a theory that is neither as positivist as Ackerman's own theory of dualism nor as naturalist as his portrayal of rights foundationalism.

4. Ackerman, We the People at 3 (cited in note 2).

5. Sanford Levinson, blurb on dust jacket of We the People. See also Sanford Levinson, Accounting for Constitutional Change, 8 Const. Comm. 409, 429 (1991) (characterizing Ackerman's enterprise as "the most important and imaginative work now being done in the area of constitutional theory"). If Ackerman's We the People reopens the tradition of "American exceptionalism," perhaps his The Future of Liberal Revolution continues the tradition of American imperialism, attempting to colonize Eastern European countries (not to mention South Africa and Latin American countries) with American models and theories. See Bruce Ackerman, The Future of Liberal Revolution (Yale U. Press, 1992). Both works are thus in different ways characteristically American. Ackerman places himself in the tradition of American exceptionalism epitomized by Louis Hartz, stating: "I share with Louis Hartz an abiding skepticism about the power of European models to enlighten American politics without fundamental conceptual reorganization." Ackerman, We the People at 25 (cited in note 2) (referring to Louis Hartz, The Liberal Tradition in America (Harcourt, Brace, 1955)).

6. Ackerman, We the People at 13-16 (cited in note 2). Ackerman also discusses the German Basic Law in his treatment of liberal revolution. See Ackerman, The Future of Liberal Revolution at 101-12 (cited in note 5). In the aftermath of the unification of West Germany and East Germany, I shall speak simply of the "German Basic Law." For an analysis applying Ackerman's constitutional theory to constitutional issues raised by 
ment, asking to what extent his contrast illuminates differences between the American and German constitutional orders and adjudicates the conflicting claims of dualism and rights foundationalism to be the better account of the American scheme of government. My conclusion is that, although the American "fabrics of governments" may well be exceptional, Ackerman has not established his case for dualism over rights foundationalism.

\section{OUR ALIENABLE DUALIST CONSTITUTION?}

Ackerman argues that the American Constitution is dualist rather than rights foundationalist. Dualists conceive the Constitution as "democratic first, rights-protecting second" in the sense that judicial protection of constitutional rights against encroachments by the ordinary law of legislation "depend[s] on a prior democratic affirmation on the higher lawmaking track" of the Constitution. ${ }^{7}$ Rights foundationalists "reverse this priority," for they hold that "the Constitution is first concerned with protecting rights; only then does it authorize the People to work their will on other matters."8

German unification, see Paul Schwartz, Social Discourse and Constitutional Change: The Example of German Reunification (1994) (unpublished manuscript, on file with the author).

7. Ackerman, We the People at 13 (cited in note 2). Thus, Ackerman's theory of dualism seeks to reconstruct the classical, interpretive justification of judicial review, put forward in The Federalist No. 78 at 467, 469 (Alexander Hamilton) (cited in note 1), and Marbury v. Madison, 5 U.S. (1 Cranch) 137, 177-78 (1803): Courts are obligated to interpret the higher law of the Constitution and to preserve it against encroachments by the ordinary law of legislation. See Ackerman, We the People at 60-61, 72 (cited in note 2). In this Article, I shall not assess his distinctions between ordinary lawmaking and higher lawmaking, or between "normal politics" on the former track and "constitutional politics" on the latter track. Id. at 230-94. For discussions of these matters, see, e.g., Suzanna Sherry, The Ghost of Liberalism Past, 105 Harv. L. Rev. 918 (1992) (reviewing Ackerman, We the People (cited in note 2)); Terrance Sandalow, Abstract Democracy: A Review of Ackerman's We the People, 9 Const. Comm. 309 (1992); Michael W. McConnell, The Forgotten Constitutional Moment, 11 Const. Comm. 115 (1994). See also Symposium on Bruce Ackerman's We the People, 104 Ethics 446 (1994).

8. Ackerman, We the People at 13 (cited in note 2). For an argument that Ackerman's formulation presents a "false dichotomy" because both democracy and rights, or popular sovereignty and unalienable rights, are constitutive principles of our constitutional democracy, see Samuel Freeman, Original Meaning, Democratic Interpretation, and the Constitution, 21 Phil. \& Pub. Aff. 3,41-42 (1992). For a similar argument, though not directed specifically against Ackerman, that our constitutional order is a hybrid scheme of democracy (majority rule) and constitutionalism (limited government), or constitutional democracy, see, e.g., Walter F. Murphy, James E. Fleming, and William F. Harris II, American Constitutional Interpretation 23-46 (Foundation Press, 1986); Walter F. Murphy, Constitutions, Constitutionalism, and Democracy, in Douglas Greenberg et al. eds., Constitutionalism and Democracy: Transitions in the Contemporary World 3, 3-7 (Oxford U. Press, 1993) ("Constitutions, Constitutionalism, and Democracy"). 
Ackerman's argument for dualism over rights foundationalism emphasizes a contrast between the American Constitution and the German Basic Law concerning entrenchment. Our Constitution, he observes, "has never (with two exceptions ....) explicitly entrenched existing higher law against subsequent amendment by the People."9 The two exceptions are Article V's prohibition of amendments (1) affecting the African slave trade until 1808 and (2) depriving a state of equal representation in the Senate without its consent. The Basic Law, by contrast, "explicitly declared that a long list of fundamental human rights cannot constitutionally be revised, regardless of the extent to which a majority of Germans support repeal."10 Article 79(3) entrenched unalienable human rights to dignity, the fundamental principles of free democratic basic order, and the basic structure of federalism. ${ }^{11}$

Ackerman submits that practices regarding entrenchment provide an important crucible for testing whether a constitutional order is dualist or rights foundationalist.12 $\mathrm{He}$ contends that the absence of "German-style entrenchment" of fundamental rights in the American Constitution-and thus their repealability or alienability-is an "embarrassment" for rights foundationalists but not for dualists. ${ }^{13} \mathrm{He}$ also states that our constitutional experience with entrenchment, through the two exceptions involving slavery and federalism, has been "very negative" and has not

9. Ackerman, We the People at 13 (cited in note 2).

10. Id. at $\mathbf{1 5}$ (emphasis in original).

11. Article 79(3) of the German Basic Law provides in relevant part: "Amendments of this Basic Law affecting the division of the Federation into Laender, the participation on principle of the Laender in legislation, or the basic principles laid down in Articles 1 and 20 , shall be inadmissible." Articles 1 and 20 relate to the protection of unalienable human rights to dignity and the free democratic basic order, specifically, the right to resist any person or persons seeking to abolish the constitutional order, a democratic and social federal state. For a translation of portions of The Basic Law of the Federal Republic of Germany, see Walter F. Murphy and Joseph Tanenhaus eds., Comparative Constitutional Law: Cases and Commentaries (St. Martin's Press, 1977) ("Comparative Constitutional Law"). For analyses of the constitutional theory of the Basic Law, and of its entrenchment of certain basic principles against subsequent amendment, see, e.g. John E. Finn, Constitutions in Crisis: Political Violence and the Rule of Law 185-91 (Oxford U. Press, 1991) ("Constitutions in Crisis"); Donald P. Kommers, The Constitutional Jurisprudence of the Federal Republic of Germany 36-39, $52-55$ (Duke U. Press, 1989); Walter F. Murphy, Excluding Political Parties: Problems for Democratic and Constitutional Theory, in Paul Kirchhof and Donald P. Kommers eds., Germany and Its Basic Law 173, 173-78 (Nomos Verlagsgesellschaft, 1993) ("Excluding Political Parties").

12. Ackerman, We the People at 13 (cited in note 2).

13. Id. at 14. See also Bruce Ackerman, Constitutional Politics/Constitutional Law, 99 Yale L.J. 453, 469 (1989) (using the stronger formulation "a very great embarrassment"). 
served the cause of human freedom. ${ }^{14}$ From these aspects of our constitutional document and history, he concludes that rights foundationalism "is inconsistent with the existing premises of the American higher lawmaking system."15 For in America, "it is the People who are the source of rights," 16 and We the People are not bound by a higher law than the higher law of the Constitution. ${ }^{17}$ In the crucible of entrenchment, Ackerman argues, ours proves to be an alienable dualist Constitution, unlike the unalienable rights foundationalist Basic Law.

Should we be persuaded by Ackerman's argument for dualism from his contrast between the American Constitution and the German Basic Law? Are practices of entrenchment a good crucible in which to test the basic commitments of a constitutional order? Or is Ackerman's test rigged in favor of a positivist dualism?

Early British legal positivists like John Austin believed that, to get to the bottom of a legal system, one had to find a sovereign, "a legally untrammelled will" behind the legislature that was free, "not only from legal limitations imposed $a b$ extra, but also from its own prior legislation."18 Sophisticated contemporary positivists like H.L.A. Hart have argued instead that the foundation of a legal system is an accepted rule of recognition specifying the ultimate criteria of legal validity. 19 Ackerman has stated that his aim in constitutional theory is to develop a "principled positivism" in the form of a theory of dualist democracy that would provide "principles of recognition" of higher lawmaking (by analogy to Hart's idea of rules of recognition). ${ }^{20}$ Under

14. Ackerman, We the People at 15 (cited in note 2) (referring to entrenchment of African slave trade until 1808). See also id. at $326 \mathrm{n} .21$ (referring to entrenchment of equal representation of each state in the Senate and claiming that "[t]his effort to entrench federalism caused all sorts of trouble in the aftermath of the Civil War").

15. Id. at 15 .

16. Id.

17. In using formulations like that in the text ("We the People are not bound by a higher law") or in the title ("We the Exceptional American People"), I do not intend to personify the constituent power, that is, to conflate the citizenry (the people) with the constituent power (We the People). For a sophisticated treatment of the difference between the "Constitutional People" and the "sovereign constitution-making people," see William F. Harris, II, The Interpretable Constitution 201-04 (Johns Hopkins U. Press, 1993).

18. H.L.A. Hart, The Concept of Law 145 (Clarendon Press, 1961) (analyzing John Austin, The Province of Jurisprudence Determined (H.L.A. Hart ed., Weidenfeld and Nicholson, 1954) (1832)). See also id. at 70-76 (analyzing the positivist idea of "The Sovereign behind the Legislature").

19. Id. at 97-107.

20. Bruce Ackerman, Remarks at New York University School of Law Colloquium on Constitutional Theory, Nov. 16, 1993 (colloquy between Ackerman and Ronald Dworkin). 
Ackerman's positivist theory of popular sovereignty, We the People are free, not only from limitations imposed $a b$ extra by unalienable rights, but also from our own prior higher lawmaking. 21

With this background in mind, we should ask whether the fact that our Constitution lacks entrenchment clauses of the sort expressed in the German Basic Law proves, as Ackerman maintains, that it is dualist rather than rights foundationalist. In answering this question, we should consider the strong likelihood that an unrelenting positivist dualist applying Ackerman's crucible of entrenchment would contend that the German Basic Law, like the American Constitution, is ultimately dualist. According to such a positivist, Article 79(3) of the Basic Law would not, in Hart's terms, put a stop to the chain of inquiries concerning legal validity; 22 she or he would insist on pressing further to find the legally untrammelled will or sovereign standing behind the entrenchment clauses. (The proof of this speculation lies in Ackerman's suggestion that the Basic Law may have an "escape hatch" (Article 146) through which German dualists might prevail over German rights foundationalists by repealing the limitations of Article 79(3) and thereby modifying the Basic Law's foundationalist commitments. ${ }^{23}$ ) From the standpoint of such a positivist dualism, entrenchment clauses in a written constitution are-to quote Chief Justice John Marshall from an analogous context"absurd attempts, on the part of the people, to limit a power, in its own nature illimitable." 24

21. Ackerman, We the People at $13-16$ (cited in note 2).

22. See Hart, The Concept of Law at 104 (cited in note 18).

23. Ackerman, We the People at 326 n.20 (cited in note 2). Ackerman observes that the Basic Law (Grundgesetz), in Article 146, allows for its replacement by a completely new Constitution (Verfassung). Id. He writes: "Since the drafters of the Basic Law took this step to emphasize the provisional character of West Germany [pending reunification with East Germany], and not the provisional character of fundamental rights, it would be a great abuse of art. 146 to use the occasion of a new Verfassung to modify the entrenched provisions on human rights." Id. He concludes: "Nonetheless, this technical possibility does provide an escape hatch through which German dualists might conceivably modify their Basic Law's foundationalist commitments." Id.

Originally, Article 146 provided: "This Basic Law shall cease to be in force on the day on which a constitution adopted by a free decision of the German people comes into force." Murphy and Tanenhaus, Comparative Constitutional Law at 22-23 (cited in note 11). As it turned out, the Basic Law was not replaced by a completely new Constitution during the process of reunification of West Germany and East Germany. For constitutional analyses of German reunification, see Peter E. Quint, The Constitutional Law of German Unification, 50 Md. L. Rev. 475 (1991); Schwartz, Social Discourse and Constitutional Change: The Example of German Reunification (cited in note 6).

24. Marbury v. Madison, 5 U.S. (1 Cranch) 137, 177 (1803). In the quoted passage, Chief Justice Marshall is not discussing entrenchment clauses, but instead is advancing the 
Furthermore, even a rights foundationalist could admit, as John Rawls writes, that "in the long run a strong majority of the electorate can eventually make the constitution conform to its political will." 25 But, Rawls continues: "This is simply a fact about political power as such. There is no way around this fact, not even by entrenchment clauses that try to fix permanently the basic democratic guarantees." 26 This fact about political power, however, is not the foundation of legitimacy in either the American or the German constitutional order.27 Nor does it prove that, at bottom, our Constitution is dualist rather than rights foundationalist. Ackerman's crucible of entrenchment is a rigged positivist test.

If practices of entrenchment do not tell us whether we have a dualist or a rights foundationalist constitutional order, can they tell us anything? One way to explore this matter is to ask what the purposes of entrenchment are. Let us posit a positivist-less relentless than the one we just imagined-who believes that if you want to know the constitutive principles on which a constitutional order is founded (and nothing else), you must look at it as an entrenchment formalist, and examine what provisions are explicitly entrenched in the constitutional document against subsequent amendment.28 Applying this test, the positivist would conclude from Article 79(3) of the German Basic Law that the

classical, interpretive justification of judicial review under a written constitution. See supra note 7.

25. John Rawls, Political Liberalism 233 (Colum. U. Press, 1993).

26. Id. See also Walter F. Murphy, An Ordering of Constitutional Values, $53 \mathrm{~S}$. Cal. L. Rev. 703, 757 (1980) (conceding that "[a]s a matter of sheer power, the people can give themselves a new constitutional order" by repudiating a constitutional document's protection of unalienable human rights to dignity, but contending that the terms of the current constitutional document "cannot supply legitimate procedures" for destroying the old constitutional order and creating a new one); Walter F. Murphy, Merlin's Memory: The Past and Future Imperfect of the Once and Future Polity, in Sanford Levinson ed., Responding to Imperfection (Princeton U. Press, forthcoming 1995) ("Merlin's Memory") (discussing the issue of the extent to which "the people can bind themselves").

27. I do not mean to deny that one could attempt to provide a justification for a constitutional theory of popular sovereignty or positivist dualism like Ackerman's on the basis of a normative political theory. Ackerman, however, has not elaborated such foundations for his constitutional theory, notwithstanding his title (We the People: Foundations). Indeed, Ackerman has stated-in terms of Ronald Dworkin's formulation of the two dimensions of best interpretation, fit and justification, see Ronald Dworkin, Law's Empire 239 (Belknap Press, 1986); Ronald Dworkin, Taking Rights Seriously 107 (Harv. U. Press, 1977) - that "fit is everything." Remarks at New York University School of Law Colloquium on Constitutional Theory, Nov. 16, 1993 (colloquy between Ackerman and Dworkin). For suggestions that Ackerman's theory at bottom is a form of authoritarianism or formalism, see infra note 59 .

28. Cf. Oliver Wendell Holmes, The Path of the Law, in Collected Legal Papers 167, 171 (Peter Smith, 1952) ("If you want to know the law and nothing else, you must look at it as a bad man, who cares only for the material consequences which such knowledge 
constitutive principles of the German scheme of government were unalienable human rights to dignity, the fundamental principles of free democratic basic order, and the basic structure of federalism. But such a positivist would find Article $V$ of the American Constitution cryptic (or deeply unjust) on first sight: for entrenchment of protection of the African slave trade until 1808 and equal representation of the states in the Senate hardly look like constitutive principles of a constitutional order.29 This discovery might lead to either of two conclusions: that the American Constitution simply recognizes no fundamental rights as constitutive principles, or that in our constitutional document entrenchment performs a role other than that of securing constitutive principles. Ackerman basically draws the former conclusion; I shall pursue the latter.

What alternative role might Article $V$ entrenchment play in the American Constitution? Perhaps Article V entrenches provisions that reflect deep compromises with our Consitution's constitutive principles: the protection of the African slave trade with the principle that all persons are created equal, and the equal representation of the states in the Senate with the principle of the equal representation of citizens. 30 The founders of the Constitution concluded that both compromises were necessary to "the forging of the Union": the slave states insisted upon the former, the small states upon the latter. ${ }^{31}$ Thus, both imperfections were considered necessary "to form a more perfect Union" than the

enables him to predict, not as a good one, who finds his reasons for conduct, whether inside the law or outside of it, in the vaguer sanctions of conscience").

29. On one interpretation, which I offer below, these provisos in Article $V$ entrenched compromises with our constitutive principles. See infra text accompanying notes 30-33. On another interpretation, which underscores the injustice of the original Constitution, these provisos entrenched two of our constitutive principles: the fundamental right of slave holders to property in slaves and structural protections of states' rights. John Finn suggested the latter interpretation to me (without endorsing it).

30. For a suggestion that both the protection of slavery in the original Constitution and the provision for equal representation of each state in the Senate-the two matters that Article $\mathrm{V}$ entrenched against amendment-are inconsistent with the principles of "democratic reason" or "constitutional democracy," see Freeman, 21 Phil. \& Pub. Aff. at 35 (cited in note 8).

31. See Richard B. Morris, The Forging of the Union: 1781-1789, at 281-87 (Harper \& Row, 1987). See also Richard B. Bernstein (with Jerome Agel), Amending America: If We Love the Constitution So Much, Why Do We Keep Trying to Change It? 20-22 (Times Books, 1993). Akhil Amar has observed that Article V's proviso regarding the equal representation of states in the Senate was not itself part of the famous "Connecticut Compromise" between the small and large states, noting that the proviso "was not even mentioned until the penultimate day of the convention, and was voted on with virtually no discussion or analysis of its implications." Akhil Reed Amar, Philadelphia Revisited: Amending the Constitution Outside Article V, 55 U. Chi. L. Rev. 1043, 1070-71 n.97 (1988). 
Articles of Confederation. From this standpoint, contra Ackerman, we can see that Article $V$ entrenched features of the Constitution that were vulnerable to being repealed through democratic procedures, precisely because they manifested such deep compromises with our constitutive principles and ordained such an imperfect Constitution.

With this idea of the purpose of entrenchment on hand, we should reassess Ackerman's contrast between American and German practices. Ackerman may make such haste to disparage the American experience with "German-style entrenchment," and to taint it by association with slavery, that he overlooks this alternative purpose of bolstering vulnerable features of a scheme of government. Moreover, his discussion obscures a deeper similarity: both the American and German founders expressly entrenched provisions of their new constitutional orders that they considered necessary to secure the transition to a more perfect union. Again, in making the transition from the Articles of Confederation to the Constitution, the small states insisted upon equal representation in the Senate, and the slave states upon protection of the African slave trade. In the aftermath of the failures of the Weimar Constitution and the atrocities of Nazism, the founders of the Federal Republic of Germany insisted upon entrenching certain unalienable human rights and structural principles that had been outrageously disregarded during the Nazi regime. 32

The further point is that both countries expressly entrenched the features of their new constitutional orders that were feared to be in greatest need of bolstering, and at greatest risk of repeal through democratic procedures, given their historical circumstances. As it happens, the American Constitution explicitly entrenched provisions that deeply compromised its founding principles, while the German Basic Law explicitly entrenched provisions that profoundly expressed its reconstruction principles. ${ }^{33}$ We should not, however, let this contrast concerning en-

32. See, e.g., Finn, Constitutions in Crisis at $179-93$ (cited in note 11); Kommers, The Constitutional Jurisprudence of the Federal Republic of Germany at 36-39, 52-55 (cited in note 11).

33. Ackerman might concede this point yet still contend that it cuts in favor of dualism that the American founders did not entrench unalienable rights. One response is that they did, for example, in the Preamble, the First Amendment, the Ninth Amendment, the Declaration of Independence, and the structural implications of the constitutional order. See, e.g., Harris, The Interpretable Constitution at 164-68, 191-201 (cited in note 17) (analyzing "the limits of textual amendability" and "a hierarchy of amendment sequences" that distinguishes between the limits on amendability through Article $V$ and the greater revisability of the polity through Article VII); Akhil Reed Amar, The Consent of the 
trenchment clauses obscure similarities between the constitutive principles of the two constitutional orders.

In drawing this misleadingly strong contrast between the American and German constitutional schemes, and urging Americans to "look inward" to rediscover their distinctive dualist Constitution, does Ackerman seriously mean to imply that the idea of unalienable rights is alien to American constitutional theory, or that Americans have gotten this idea from looking outward to German models and philosophers? To the contrary, the idea of unalienable rights is far more congenial to the American constitutional tradition than to the German. For one thing, British legal positivists from Bentham to Hart have characterized American jurisprudence as marked by an anti-positivist emphasis on unalienable rights. ${ }^{34}$ For another, the German Basic Law's explicit entrenchment of unalienable rights was a "forceful rejec-

Governed: Constitutional Amendment Outside Article V, 94 Colum. L. Rev. 457, 504-05 (1994) (emphasizing the Declaration of Independence, the Preamble, and the logic of a system of republican self-government in suggesting that "not everything is properly amendable," for certain higher law principles, including popular sovereignty and perhaps liberty of conscience, frame Article V itself); Amar, 55 U. Chi. L. Rev. at 1044-45 n.1 (cited in note 31) (arguing that "the First Amendment may itself be a seemingly paradoxical exception to the general rule that amendments must not be unamendable"); Walter F. Murphy, The Art of Constitutional Interpretation: A Preliminary Showing, in M. Judd Harmon ed., Essays on the Constitution of the United States 130, 150-51 (Kennikat Press, 1978) (suggesting that the First Amendment may be an "unamendable constitutional provision"); Jeff Rosen, Note, Was the Flag Burning Amendment Unconstitutional?, 100 Yale L.J. 1073, 1084-89 (1991) (arguing that there are natural rights limitations on the amending power, derived from the history and structure of the Constitution as a whole, that are expressed in the Declaration of Independence and the Ninth Amendment). Below, I shall raise the possibility of a theory of implicit or "structural entrenchments" of fundamental rights as distinguished from explicit entrenchments of them in Article V. See infra text accompanying notes 66-73.

Another response is that the American founders did not need explicitly to entrench unalienable rights. See, e.g., Freeman, 21 Phil. \& Pub. Aff. at 41 (cited in note 8). Here, I shall emphasize the latter response. It is well to recall that the original Constitution did not include a Bill of Rights, much less an entrenched one. As Hamilton wrote in The Federalist No. 84, "the Constitution is itself, in every rational sense, and to every useful purpose, A BILL OF RIGHTS." The Federalist No. 84 at 515 (Alexander Hamilton) (cited in note 1). The arguments in favor of adopting a Bill of Rights ultimately prevailed, but against this background perhaps it would have been too much to ask for an entrenched Bill of Rights. Moreover, in the historical circumstances surrounding the American founding, as contrasted with those surrounding the German reconstruction, explicit entrenchment of unalienable rights would have been unnecessary.

34. See H.L.A. Hart, 1776-1976: Law in the Perspective of Philosophy, in H.L.A. Hart, Essays in Jurisprudence and Philosophy 145, 145-52 (Clarendon Press, 1983) (discussing Bentham's famous attack on the Declaration of Independence); H.L.A. Hart, The United States of America, in H.L.A. Hart, Essays on Bentham 53, 53-65 (Clarendon Press, 1982) (same); see also H.L.A. Hart, American Jurisprudence through English Eyes: The Nightmare and the Noble Dream, in H.L.A. Hart, Essays in Jurisprudence and Philosophy $123,123-25,132-42$, supra (discussing American jurisprudence's anti-positivist concentration on rights and moral principles in the judicial decisionmaking process). 
tion of the legal positivism that grounded individual liberties in Weimar, where such rights found their source in the authority of the state." 35

The reconstruction of constitutional democracy in Germany, upon "reflection and choice," 36 was rooted not only in a rejection of Weimar constitutional theory and Nazism, but also in an acceptance of American constitutional theory and practice. After World War II, the American "fabrics of governments" served as a "model on the face of the globe." 37 The German Basic Law (not to mention the Japanese Constitution) was in no small measure made in America. 38 To some extent, therefore, when Americans look outward to the German Basic Law, they look into a mirror of their own unalienable rights and constitutive principles. In other words, to a degree the unwritten American Constitution is written into the German Basic Law, and the unalienable rights and constitutive principles underlying the American constitutional order are expressly entrenched in the German constitutional document. ${ }^{39}$

35. Finn, Constitutions in Crisis at 188 (cited in note 11). See also Kommers, The Constitutional Jurisprudence of the Federal Republic of Germany at 37-38 (cited in note 11).

36. Finn, Constitutions in Crisis at 179 (cited in note 11) (quoting The Federalist No. 1 at 33 (Alexander Hamilton) (cited in note 1)).

37. The Federalist No. 14 at 104 (James Madison) (cited in note 1).

38. I do not mean to overstate this point - for example, by implying that Americans actively participated in the drafting of the German Basic Law, that the American influence upon it was the only influence, or that the German Basic Law (and the Constitutional Court's interpretation of it) do not carry some "American" ideas further than the American Constitution, tradition, and practice have taken them. I simply mean to emphasize that the influence of American ideas upon the Basic Law was considerable, and that the contrast between these two constitutional orders is not as great as Ackerman's analysis suggests. Walter Murphy has written: "Not only did Britain, France, and the United States set the basic guidelines for the new order [the German Basic Law], but their military governors were also frequent, if seldom effective, kibitzers in the drafting process." Murphy, Excluding Political Parties at 173 (cited in note 11). (He also has observed that the Japanese document was known for several decades as "the MacArthur Constitution." Murphy, Constitutions, Constitutionalism, and Democracy at 22 n.27 (cited in note 8).) For discussions of the impact of American ideas on the German Basic Law, see, e.g., Peter H. Merkl, The Origin of the West German Republic (Oxford U. Press, 1963); John Ford Golay, The Founding of the Federal Republic of Germany (U. of Chi. Press, 1958).

39. See Murphy, 53 S. Cal. L. Rev. at 751-53 (cited in note 26). Nonetheless, there are important differences between the American Constitution and the German Basic Law, most notably with respect to the latter's provisions regarding duties and responsibilities in addition to rights. See Kommers, The Constitutional Jurisprudence of the Federal Republic of Germany at 36-37, 41-42, 56 (cited in note 11); Murphy, 53 S. Cal. L. Rev. at 753 (cited in note 26). See also Mary Ann Glendon, Rights Talk: The Impoverishment of Political Discourse 61-75 (The Free Press, 1991) (observing differences between the American conception of the person as a "lone rights-bearer" and the German image of the person as having not only rights but also responsibilities and duties to others); but see Linda C. McClain, Rights and Irresponsibility, 43 Duke L.J. 989 (1994) (criticizing Glen- 
In conclusion, the fact that the American Constitution, unlike the German Basic Law, does not explicitly entrench unalienable rights or constitutive principles does not prove that it is dualist, or "democratic first, rights-protecting second." Contrary to Ackerman's claim, the absence of provisions entrenching fundamental rights in the American Constitution is not an "embarrassment" for rights foundationalists. 40 To paraphrase the Ninth Amendment: the entrenchment in the Constitution, of certain compromises, shall not be construed to deny or disparage unalienable rights retained by the people. 41 Ackerman has failed to establish his claim that our "American exceptionalism" consists in the fact that we have an alienable dualist Constitution.

\section{OUR IMPERFECT DUALIST CONSTITUTION?}

Ackerman further argues that the general availability of repeal of fundamental rights protected in the American Constitution is an "embarrassment" for rights foundationalists but not for dualists. $42 \mathrm{He}$ contends that our Constitution, again unlike the German Basic Law, is open to "morally disastrous" amendments repealing fundamental rights. 43 To test this contention, Ackerman conjures up two hypothetical Christianity amendments. The first establishes Christianity as the state religion of the American people, thereby repealing the fundamental right to liberty of conscience. The second forbids repeal of the first, thereby entrenching it and in effect repealing freedom of speech and dualist democracy itself. ${ }^{44}$ Ackerman states that dualists would accept these amendments as valid while rights foundationalists would reject them as unconstitutional. Asserting that in America, unlike Germany, "almost all lawyers" would consider "absurd" or "preposterous" the idea that an amendment to the Constitution

don's account of the relationship between rights and responsibilities in American jurisprudence).

40. See Freeman, 21 Phil. \& Pub. Aff. at $41-42$ (cited in note 8) (quoting Ackerman, 99 Yale L.J. at 468, 469 (cited in note 13)) (arguing, contra Ackerman, that substantive fundamental rights such as liberty of conscience, along with procedural democratic rights like the right to vote, are constitutive of and inalienable in our constitutional democracy).

41. A caveat is in order here. I am drawing an analogy by paraphrasing the Ninth Amendment, not offering an interpretation of that provision. The controversies surrounding the interpretation of the Ninth Amendment are beyond the scope of this Article. See, e.g., Randy E. Barnett, ed., 1 The Rights Retained by the People (George Mason U. Press, 1989); Randy E. Barnett, ed., 2 The Rights Retained by the People (George Mason U. Press, 1993); Symposium on Interpreting the Ninth Amendment, 64 Chi.-Kent L. Rev. 1 (Randy E. Barnett, ed., 1988).

42. Ackerman, We the People at 14 (cited in note 2).

43. Id. at 14-15.

44. Id. at $14-15 \& 15-16 \mathrm{n}$. 
might be unconstitutional, Ackerman claims that dualism better fits our constitutional order than does rights foundationalism. 45

Having drawn this contrast through these two hypothetical amendments, Ackerman goes on to confess that, as a citizen and a political philosopher, he is a rights foundationalist who would be proud to be a member of the generation that "finally redeem[ed] the promise of the Declaration of Independence by entrenching inalienable rights into our Constitution," including liberty of conscience and freedom of speech. 46 We should recall that his earlier writings include Social Justice in the Liberal State, 47 a work of rights foundationalist political philosophy that bears affinities to the liberal political philosophies of John Rawls and Ronald Dworkin, from whom he now wishes to distance himself as a dualist constitutional theorist. 48 Michael Klarman has suggested that Ackerman's confession that he yearns to move "beyond dualism" to a rights foundationalist constitutional order evinces a "glaring contradiction" that undermines his commitment to popular sovereignty and raises the question "why one should take seriously Ackerman's detailed exegesis of dualist democracy." 49

Whether or not he falls into contradiction, Ackerman is straining mightily to prove his democratic and positivist mettle by proclaiming that he would uphold the validity of these hypothetical amendments as a dualist constitutional theorist, though he

45. Id. at 15 \& $15 \mathrm{n}$. Ackerman states: "I doubt, moreover, that one may find many American lawyers who seriously disagree-even among those who presently wrap themselves up in foundationalist rhetoric." Id. at 14-15. He does, however, mention Walter Murphy as "a constitutionalist who may have the courage of his foundationalist convictions." See Ackerman, 99 Yale L.J. at 470 n.28 (cited in note 13) (citing Walter F. Murphy, Slaughter-House, Civil Rights, and the Limits on Constitutional Change, 32 Am. J. Juris. 1 (1987)). For analyses of the German constitutional order and judicial practice in this respect, see, e.g., Murphy, 53 S. Cal. L. Rev. at 754-57 (cited in note 26) (discussing The Southwest Case, 1 BVerfGE 14 (1951)); Finn, Constitutions in Crisis at 186 (cited in note 11) (same). See also supra note 33 (citing arguments that the American Constitution entrenches certain unalienable rights against repeal).

46. Ackerman, We the People at 321 (cited in note 2). See also id. at 16.

47. Bruce A. Ackerman, Social Justice in the Liberal State (Yale U. Press, 1980).

48. Ackerman, We the People at 11 (cited in note 2) (referring to John Rawis, Kantian Constructivism in Moral Theory, 77 J. Phil. 515 (1980); Dworkin, Taking Rights Seriously (cited in note 27); and Dworkin, Law's Empire (cited in note 27)). But see id. at 30, 327-28 n.49 (noting that his own work in political philosophy builds on the liberal tradition that includes Rawls); Bruce Ackerman, Political Liberalisms, 91 J. Phil. 364 (1994) (criticizing Rawls, Political Liberalism (cited in note 25), while also acknowledging similarities between Rawls's political philosophy and his own).

49. Michael J. Klarman, Constitutional Fact/Constitutional Fiction: A Critique of Bruce Ackerman's Theory of Constitutional Moments, 44 Stan. L. Rev. 759, 763-64 n.37 (1992). Ackerman presumably would contend that there is no "glaring contradiction" between being a dualist constitutional theorist and being a rights foundationalist political philosopher. See Ackerman, We the People at 16, 319-22 (cited in note 2). 
would hold them "morally disastrous" as a rights foundationalist political philosopher. With all the zeal of a born-again positivist who has seen the errors of his rights foundationalist past, Ackerman kneels before the altar of Henry Monaghan's "Imperfect Constitution," 50 striving to show that his constitutional theory passes what Christopher Eisgruber has dubbed Monaghan's "no pain, no claim" test.51 (Basically, the idea is that a constitutional theory has no serious claim on our attention unless the theorist putting it forward suffers some pain by acknowledging that the Constitution does not secure everything that she or he would protect in a perfect Constitution.52) Indeed, Ackerman does more than confess his past as a rights foundationalist, for he also admits his present temptation to move beyond dualism to rights foundationalism and to entrench a new Bill of Rights against subsequent amendment.53 Yet he maintains that he does not succumb, proving his democratic and positivist virtue by unveiling his imperfect dualist Constitution. 54

Through this argument for dualism from the two hypothetical Christianity amendments, Ackerman is attempting to deliver a coup de grace against rights foundationalists of the sort that would be made by Article V positivists like Robert Bork. ${ }^{55}$ Their

50. See Henry P. Monaghan, Our Perfect Constitution, 56 N.Y.U. L. Rev. 353, 395 (1981).

51. See Christopher L. Eisgruber, Justice and the Text: Rethinking the Constitutional Relation Between Principle and Prudence, 43 Duke L.J. 1, 7 (1993) (referring to Monaghan, 56 N.Y.U. L. Rev. 353 (cited in note 50)). But liberal rights foundationalists should not despair. On the evidence of Ackerman's We the People, they should rest assured that his constitutional theory will legitimate almost anything that they believe the Constitution protects, although in the name of We the People, not unalienable fundamental rights. See also Bruce Ackerman, Liberating Abstraction, 59 U. Chi. L. Rev. 317 (1992).

52. For the idea of a "Constitution-perfecting" theory, as distinguished from a "process-perfecting" theory, see Fleming, 72 Tex. L. Rev. 211 (cited in note 3) (advancing a Constitution-perfecting theory of judicial review of ordinary lawmaking without taking up the issue of judicial review of higher lawmaking). I mean "perfecting" in the sense of interpreting the Constitution with integrity so as to render it as a coherent whole, not in Monaghan's caricatured sense of "Our Perfect Constitution" as a perfect liberal utopia or an "ideal object" of political morality. See Monaghan, 56 N.Y.U. L. Rev. at 356 (cited in note 50). Cf. Frank I. Michelman, Constancy to an Ideal Object, 56 N.Y.U. L. Rev. 406-07 (1981) (distinguishing "weak-sense perfectionism" or "constitutional rationalism" from "strong-sense perfectionism"). For the idea of amendments to the Constitution as responding to imperfection, see Sanford Levinson, ed., Responding to Imperfection (Princeton U. Press, forthcoming 1995).

53. Ackerman, We the People at 16, 319-22 (cited in note 2). For the notion of "temptation," see Robert H. Bork, The Tempting of America: The Political Seduction of the Law (The Free Press, 1990) ("The Tempting of America").

54. Ackerman, We the People at 15-16 (cited in note 2).

55. See Bork, The Tempting of America (cited in note 53). (For Bork's discussion of Ackerman's theory, see id. at 214-16; for Ackerman's critique of Bork's theory, see Bruce Ackerman, Robert Bork's Grand Inquisition, 99 Yale L.J. 1419 (1990) (reviewing Bork, 
last move, in trying to place the American Constitution in the camp of popular sovereignty rather than unalienable fundamental rights, would be to assert that under the amending procedures of Article V, We the People have ultimate constitutional authority to "alter any feature of the [constitutional] document including its commitment to basic liberties and constitutional forms." 56

Now, this type of move is to be expected from an Article $V$ positivist like Bork. But such a move is, to say the least, surprising coming from Ackerman. After all, he has spent the last decade developing a complex theory of amending the Constitution outside Article $V$ through structural amendments. ${ }^{57}$ Yet here we find Ackerman talking like an Article $V$ positivist with respect to repealability and entrenchment. In this essay, I can only briefly state three points in response.

The first point concerns Ackerman's evident strategy for winning acceptance of his complex constitutional theory among lawyers. He assumes that lawyers are low-level positivists who would reject out of hand rights foundationalist theories that presuppose that unalienable rights or constitutive principles are implicitly entrenched in the constitutional order (outside Article $\mathrm{V}$ ), though not explicitly entrenched in the constitutional document (in Article V). Ackerman's tack is apparently to join such positivist lawyers and then to try to enlist them - through an appeal to lawyerly criteria of fit with our constitutional document and underlying constitutional order-on the side of dualism and against rights foundationalism. ${ }^{58}$ The strategy is basically if you can't beat the positivist lawyers, join them, and then hope that they will join you. I mean to intimate shades of Suzanna Sherry's

supra)). For discussion of the sort of coup de grace to be expected from someone with commitments like Bork's, see Stephen Macedo, Liberal Virtues: Citizenship, Virtue, and Community in Liberal Constitutionalism 182 (Oxford U. Press, 1990) ("Liberal Virtues").

56. Macedo, Liberal Virtues at $\mathbf{1 8 2}$ (cited in note 55).

57. See, e.g., Ackerman, We the People at 266-94 (cited in note 2); Bruce A. Ackerman, Discovering the Constitution, 93 Yale L.J. 1013, 1051-57 (1984); Ackerman, 99 Yale L.J. at 486-515 (cited in note 13). Ackerman is not the only constitutional theorist who rejects the exclusivity of Article V's formal amending procedures. See also Amar, $55 \mathrm{U}$. Chi. L. Rev. 1043 (cited in note 31); Amar, 94 Colum. L. Rev. 457 (cited in note 33).

58. See, e.g., Ackerman, We the People at 15, $15 \mathrm{n}$. (cited in note 2) (appealing to what "almost all lawyers" would think was "absurd" or "preposterous"). In remarks at the New York University School of Law Colloquium on Constitutional Theory, November 16, 1993, Ackerman made repeated recourse to "lawyerly criteria of fit," which he linked to his concern in his writings for "the possibility of interpretation." See, e.g., Ackerman, We the People at 131-62 (cited in note 2); Ackerman, 93 Yale L.J. at 1070-72 (cited in note 57); Ackerman, 99 Yale L.J. at 515-45 (cited in note 13). 
interpretation of Ackerman's dualism, in the guise of a liberal originalism, as "the ghost of liberalism past." 59

Strategically, Ackerman would be prudent to ponder the great likelihood that positivist lawyers who would join him in rejecting rights foundationalist ideas of implicit entrenchment of constitutive principles or unalienable rights outside Article $\mathrm{V}$ as absurd or preposterous would also stand ready to join positivists like Bork in rejecting as preposterous and absurd Ackerman's own idea of amendment of the Constitution outside Article V. That is, lawyers who are Article $V$ positivists regarding entrenchment are also quite likely to be Article $\mathrm{V}$ positivists concerning amendment. They are usually the sort of people who contend that the words of Article V "mean what they say"60 or that the whole point of Article $\mathrm{V}$ is to have a "clear rule of recognition for constitutional change."61 In short, such positivist lawyersAckerman's new-found allies-probably would use Article $\mathrm{V}$ as a coup de grace against his own theory of structural amendments. Ironically, notwithstanding Ackerman's attempt to portray himself as a positivist, 62 the positivists are the persons who are least likely to be persuaded by his theory.

My second point is that Ackerman himself, despite his best efforts, does not sound like an Article $V$ positivist when discussing the two hypothetical Christianity amendments. For example, he does not say simply that the hypothetical amendment repealing liberty of conscience is valid, because it has been ratified through Article $\mathrm{V}$ procedures. Instead, he concedes that it would inaugurate a "deep transformation" of our Constitution: "on more or less the same order, though of a very different kind," as the transformations to new "regimes" within dualist democracy achieved by the Reconstruction Republicans and New Deal Democrats. ${ }^{63}$ Nor does Ackerman say simply that the hypothetical amendment entrenching such a repeal is valid, because the

59. See Sherry, 105 Harv. L. Rev. at 933-34 (1992) (cited in note 7) (suggesting that Ackerman's "originalism" reveals "the sad state of American liberalism" and that "[t]here is genuine pathos in seeing what was once the most optimistic and forward-looking of the American political philosophies reduced in this appeal to the authority of the past"). See also Frank Michelman, Law's Republic, 97 Yale L.J. 1493, 1521-23 (1988) (interpreting Ackerman's dualism as a form of authoritarianism); Cass R. Sunstein, The Partial Constitution 370 n.21 (Harv. U. Press, 1993) (suggesting that Ackerman's theory is formalist).

60. David R. Dow, When Words Mean What We Believe They Say: The Case of Article $V, 76$ lowa L. Rev. 1 (1990).

61. Klarman, 44 Stan. L. Rev. at 766 (cited in note 49).

62. See supra text accompanying note 20 .

63. Ackerman, We the People at 14 (cited in note 2). For Ackerman's argument for a "regime perspective," or for conceiving our constitutional history in terms of three re- 
voice of the People has duly spoken. Rather, he states that it would amount to a "repeal of dualist democracy itself."64 That is, the latter amendment would go beyond the former's deep transformation within dualist democracy to a repeal of that order. It might amount to a constitutional breakdown or revolution, ushering in a new constitutional order altogether. 65

The implication is that Ackerman himself acknowledges that principles such as liberty of conscience and freedom of speech, even if they are not explicitly entrenched in our constitutional document, are nonetheless fundamental rights that partly constitute the identity of regimes within our constitutional order or of that order itself. Indeed, on Ackerman's account, freedom of speech, at least as expressed in participation in the amending process, might be unalienable.66 My claim is not that Ackerman here commits himself to a theory that the Constitution implicitly entrenches constitutive principles or fundamental rights outside Article V-only that his theory is not as far from such a conception as might appear on first sight.

This suggestion brings me to the third point: Just as Ackerman has elaborated a theory of "structural amendments" to the Constitution outside the formal Article $\mathrm{V}$ amending procedures, ${ }^{67}$ so one might develop a theory of "structural entrenchments" of fundamental rights or constitutive principles outside Article V. Ackerman rejects rights foundationalist theories that hold that certain fundamental rights are pre-constitutional principles that bind even constitutional framers and ratifiers at the

gimes or republics (those inaugurated by the Founding, Reconstruction, and the New Deal), see id. at 58-67.

64. Id. at 15-16 n. Ackerman's implicit distinction between "deep transformations" within dualist democracy and a "repeal of dualist democracy itself" bears a resemblance to Murphy's distinction between amending a constitutional order (correcting, adjusting, or modifying it) and repudiating it (destroying it and creating another one). See, e.g., Murphy, Constitutions, Constitutionalism, and Democracy at 14 (cited in note 8); Murphy, 53 S. Cal. L. Rev. at 757 (cited in note 26). The Supreme Court of California, drawing a distinction between "amendment" and "revision," struck down a state constitutional amendment, adopted by referendum, that would have required state judges, when interpreting the state constitution, to follow the United States Supreme Court's interpretations of similarly worded clauses in the national constitutional document. See Murphy, Merlin's Memory (cited in note 26) (discussing Raven v. Deukmejian, 801 P.2d 1077 (Cal. 1990)). The Court reasoned that such a change "would so fundamentally transform California's status as a member of a federal union as to effect a constitutional revision; and the [constitutional] text provided that 'revisions' could be accomplished only by special conventions." Id.

65. See infra text accompanying note 71 .

66. See Ackerman, We the People at 15-16 n. (cited in note 2); see also supra note 33 (citing arguments that the American Constitution entrenches certain unalienable rights against repeal).

67. See supra text accompanying note 57 . 
founding, when they are establishing a constitutional order.68 Whatever one thinks of such theories, one might advance a theory that certain constitutive principles or fundamental rights become entrenched against repeal through long and successful constitutional tradition and practice.69 Responding to Ackerman's hypothetical Christianity amendments along these lines, Rawls suggests that our constitutional tradition and practice over two centuries place restrictions upon the formal amending procedures of Article V.70 On this view, Ackerman's hypotheticals, instead of being valid amendments of the Constitution, would amount to a constitutional breakdown, or revolution in the proper sense. 71 Moreover, this view entails that entrenchment is not purely positivist and confined to Article $\mathrm{V}$ (any more than amendment is for Ackerman's theory). 72

The possibility of a theory of this sort underscores an evident incongruity in Ackerman's theory: Ackerman supplements Article $\mathrm{V}$ where structural amendments are concerned but would invoke Article $\mathrm{V}$ as a positivist bar to structural entrenchments of fundamental rights at the founding or through constitutional tradition and practice. 73 I do not claim that a theory of structural entrenchments would permanently fix basic constitutional guarantees, or perpetually impose pre-constitutional principles upon We the People. In fact, structurally entrenched fundamental rights or constitutive principles, like explicitly entrenched ones, will give way to a strong majority that is determined to make the Constitution conform to its political will. But again, this is simply a fact about political power as such,74 not a fact that unveils an ultimate rule of recognition or source of legitimacy in popular

68. See Ackerman, We the People at 11-13 (cited in note 2). For the idea of "preconstitutional principles" that bind even framers and ratifiers, see Finn, Constitutions in Crisis at 7,186, 188 (cited in note 11).

69. Let us say "moderately successful," so as not to seem Panglossian about our constitutional tradition and practice, which have been marred by many injustices.

70. Rawls, Political Liberalism at 238-39 (cited in note 25). See also Macedo, Liberal Virtues at $182-83$ (cited in note 55).

71. Rawls, Political Liberalism at 239 (cited in note 25); Freeman, 21 Phil. \& Pub. Aff. at 41-42 (cited in note 8 ).

72. For arguments that neither amendment nor entrenchment is purely positivist and confined to the formal procedures of Article V, see, e.g., Amar, 94 Colum. L. Rev. 457 (cited in note 33); Amar, 55 U. Chi. L. Rev. 1043 (cited in note 31).

73. Ackerman presumably would deny that there is any real incongruity in this respect. He might advance a ratchet theory concerning We the People, contending that it is one thing to expand popular sovereignty through a theory of amending the Constitution outside Article $\mathrm{V}$, but quite another to contract it through a theory of entrenching the Constitution outside Article V.

74. See Rawls, Political Liberalism at 233 (cited in note 25) (discussed supra text accompanying notes $25-26$ ). 
sovereignty in an imperfect American Constitution as distinguished from the (perhaps) more perfect German Basic Law.

The question what is the Constitution-and when does it become a different Constitution through breakdown or revolution-is analytically distinct from the question whether courts are empowered to declare amendments (or original provisions) unconstitutional.75 And so, even if we decide to reject Ackerman's Article $\mathrm{V}$ positivism concerning entrenchment of constitutive principles or fundamental rights in the Constitution, there remains his contrast between American and German judicial practices. He asserts that in America, judicial review invalidating "morally disastrous" amendments would seem "absurd" or "preposterous" to "almost all lawyers," whereas in Germany it would not.76 From this contrast, Ackerman argues that our scheme of government is dualist, while the German scheme is rights foundationalist.

Ackerman overstates the significance of this contrast. Initially, one might express doubts whether hypotheticals concerning judicial review of unconstitutional amendments to our Constitution provide a good crucible in which to test whether almost all lawyers are dualists or rights foundationalists. After all, most American lawyers probably have never thought about the possibility of limitations on the amending power and, if asked about it, probably would simply make the immediate observation that the idea of an "unconstitutional constitutional amendment" seems like a contradiction in terms or a paradox. But this idea seems so only to those who beg the question by unreflectively assuming a false equivalence among the amending power, the Constitution, and the constituent power. ${ }^{77}$ If pressed beyond this

75. For the distinction between theory of the Constitution and theory of judicial review (and between the interrogatives what is the Constitution and who may authoritatively interpret it), see, e.g., Murphy, Fleming, and Harris, American Constitutional Interpretation 9-12 (cited in note 8); Sotirios A. Barber, On What the Constitution Means 19699 (Johns Hopkins U. Press, 1984); Sotirios A. Barber, The Constitution of Judicial Power 40-43 (Johns Hopkins U. Press, 1993). See also Sanford Levinson, Constitutional Faith 9. 53 (Princeton U. Press, 1988).

76. See Ackerman, We the People at $15,15 \mathrm{n}$. (cited in note 2). See also supra text accompanying note 45 . In referring to German judicial practice, Ackerman cites no cases but presumably is alluding to cases like The Southwest Case, 1 BVerfGE 14 (1951), and Privacy of Communications Case, 30 BVerfGE 1 (1970). These two cases are edited and translated in Murphy and Tanenhaus, Comparative Constitutional Law at 208-12, 659-66 (cited in note 11). Murphy has observed that the Supreme Court in India has voided amendments, as has the Supreme Court of California. Murphy, Constitutions, Constitutionalism, and Democracy at 11 \& $23 \mathrm{nn} .39-40$ (cited in note 8).

77. I cannot pursue these complex matters here. For sophisticated discussions of such issues, see, e.g., Harris, The Interpretable Constitution at 164-204 (cited in note 17); Barber, On What the Constitution Means at 199-202 (cited in note 75); Hart, The Concept 
immediate reaction, almost all lawyers might also believe that to adopt amendments purporting to repeal certain unalienable fundamental rights (such as freedom of speech and liberty of conscience) would be to repudiate our constitutional order, not merely to ratify a valid constitutional amendment. 78

In any event, in assessing Ackerman's account of American judicial practice, we should distinguish between two types of situations in which an assertion regarding judicial review might be dismissed as absurd or preposterous. In the first, judicial review would seem absurd because it is unprecedented (or novel). In the second, it would seem absurd because it is contrary to well established precedents (or settled). To illustrate the first situation: in 1946, Justice Frankfurter might have said that representation-reinforcing judicial review of malapportioned legislatures would be absurd;79 or in 1922, a country lawyer named Hugo Black might have lamented that "absolutist" judicial review enforcing the First Amendment against both the state and federal governments would be absurd;80 or again, in 1937, Ackerman's forebears might have despaired that President Franklin Roosevelt was launching a court-packing plan instead of seizing a crucial moment to amend the Constitution through the formal procedures of Article V, because the idea of structural amendments to the Constitution outside Article $\mathrm{V}$ would be preposterous. ${ }^{81}$ To illustrate the second situation: today, one might argue, despite Richard Epstein, that judicial review invalidating the New Deal and the welfare state that has grown up on its foundations would be absurd. 82

Which of these two types of situations does Ackerman mean to invoke in claiming that in America judicial review declaring amendments unconstitutional would seem absurd or preposter-

of Law at 144-50 (cited in note 18); H.L.A. Hart, Self-referring Laws, in H.L.A. Hart, Essays in Jurisprudence and Philosophy 170 (cited in note 34).

78. For a distinction between amending a constitutional order and repudiating it, see supra note 64 .

79. See Colegrove v. Green, 328 U.S. 549, 556 (1946) (arguing that courts ought to stay out of that "political thicket"). By "representation-reinforcing" judicial review, I refer to the type of theory epitomized by John Hart Ely, Democracy and Distrust: $A$ Theory of Judicial Review (Harv. U. Press, 1980) ("Democracy and Distrust").

80. See Charles L. Black, Jr., Further Reflections on the Constitutional Justice of Livelihood, 86 Colum. L. Rev. 1103, 1116 (1986).

81. For Ackerman's discussion of FDR's choices between launching a court-packing plan and fighting for constitutional amendments through the formal procedures of Article V, see Bruce Ackerman, We the People: Transformations, Chapter 14 ("Court-Packing and Its Aftermath") (Fall 1993 draft, presented at New York University School of Law Colloquium on Constitutional Theory, Nov. 16, 1993).

82. See Richard A. Epstein, Takings: Private Property and the Power of Eminent Domain (Harv. U. Press, 1985). 
ous to almost all lawyers? Evidently the first rather than the second. Ackerman does not appear to argue that in America there is a well established practice against judicial review of amendments to assure conformity with constitutive principles, only that there is no well established practice in favor of such review.83 To be sure, there are cases rejecting the idea that a duly ratified amendment might be unconstitutional (which Ackerman does not cite) .84 But those cases were easy. For example, one basically upheld the Eighteenth Amendment against an argument that it was beyond the Article $\mathrm{V}$ amending power to prohibit the manufacture, sale, transportation, importation, and exportation of intoxicating liquors for beverage purposes. ${ }^{85}$ Another essentially upheld the Nineteenth Amendment against a contention that it deprived unconsenting states of their sovereign power to deny women the right to vote and thereby destroyed their autonomy as political bodies. ${ }^{86}$ Furthermore, such cases date from an era-1920 and 1922, respectively - in which "representationreinforcing" review of ordinary lawmaking might have seemed hardly less absurd than "sovereignty-reinforcing" review of higher lawmaking. ${ }^{87}$ I mention these complex matters not to resolve them but rather to suggest that our practices regarding judicial review may not be as settled as Ackerman's argument presumes.

Put another way, the question whether the Supreme Court has authority to declare amendments (or original provisions) unconstitutional presents a case of what Hart would call uncertainty in the penumbra of the ultimate rules of recognition. ${ }^{88}$ In resolv-

83. Indeed, Ackerman rejects a common interpretation of Coleman v. Miller, 307 U.S. 433 (1939), which some scholars read as precluding judicial review of the amending process on the ground that such matters are nonjusticiable political questions. See Ackerman, 99 Yale L.J. at 492-99 (cited in note 13). He argues that Coleman expressly repudiates the formalist view that "all constitutional change must be governed in strict accord with the rules of Article Five." Id. at 492.

84. The cases are discussed in Harris, The Interpretable Constitution at 187-201 (cited in note 17).

85. National Prohibition Cases, 253 U.S. 350 (1920). See also United States v. Sprague, 282 U.S. 716 (1931).

86. Leser v. Garnett, 258 U.S. 130 (1922).

87. For the idea of "sovereignty-reinforcing" judicial review of amendments to the Constitution, by analogy to Ely's notion of "representation-reinforcing" judicial review of legislation and administration, see Harris, The Interpretable Constitution at 195 (cited in note 17) (referring to Ely, Democracy and Distrust (cited in note 79)). I am aware that footnote four of United States v. Carolene Products Co., 304 U.S. 144, 152-53 n.4 (1938), cites precedents from the 1920's (and 1930's) for what we now would call "representationreinforcing" judicial review. But it took Justice Stone's footnote to pull together and systematize these precedents into the intimations of such an approach, and only later were these precedents fully comprehended as applying (or anticipating) it.

88. See Hart, The Concept of Law at 144-50 (cited in note 18). 
ing such questions, as Hart aptly put it: "Here all that succeeds is success. ... Here power acquires authority ex post facto from success." 89

In this light, the glaring difficulty with the idea of judicial review preserving the constitutive principles or fundamental rights of our Constitution against repeal is not so much absurdity or preposterousness as it is probable futility. We all know the standard moves concerning the impotence of the "least dangerous branch": for example, quotations from The Federalist No. 78,90 President Andrew Jackson,91 James Bradley Thayer, 92 Judge Learned Hand, ${ }^{93}$ and John Hart Ely.94 Yet we all also know the common countermoves: for example, hypotheticals about the possibility of judicial civil disobedience 95 and the observation that, our fears of futility notwithstanding, after ordered to do so

89. Id. at 149,150 .

90. In describing the judiciary as the branch of government that is "the least dangerous to the political rights of the Constitution," Alexander Hamilton wrote: "It may truly be said to have neither FORCE nor WILL but merely judgment; and must ultimately depend upon the aid of the executive arm even for the efficacy of its judgments." The Federalist No. 78 at 465 (Alexander Hamilton) (cited in note 1).

91. In response to Worcester v. Georgia, 31 U.S. (6 Pet.) 515 (1832), in which the Supreme Court per Chief Justice Marshall held that Georgia's anti-Cherokee laws were unconstitutional, President Jackson supposedly said: "Well, John Marshall has made his decision, now let him enforce it!" Edward S. Corwin, The President: Office and Powers 64 (New York U. Press, 4th ed., 1957). This legend, however, has been disputed. Id. at 35051 n.61.

92. James B. Thayer, The Origin and Scope of the American Doctrine of Constitutional Law, 7 Harv. L. Rev. 129, 156 (1893) ("Under no system can the power of courts go far to save a people from ruin; our chief protection lies elsewhere"). For a new interpretation of this passage from Thayer, see Mark Tushnet, Thayer's Target: Judicial Review or Democracy?, 88 Nw. U. L. Rev. 9 (1993).

93. Learned Hand, The Spirit of Liberty, in Irving Dilliard ed., The Spirit of Liberty 189,190 (Alfred A. Knopf, 3d ed., 1960) ("Liberty lies in the hearts of men and women; when it dies there, no constitution, no law, no court can save it .... While it lies there it needs no constitution, no law, no court to save it").

94. Ely, Democracy and Distrust at 107 (cited in note 79) ("courts will tend to be swept along by the same sorts of fears" that moved legislatures, executives, and, for that matter, citizens). The fear of "futility" thesis often goes hand in hand with the fear of "destruction" thesis. See id. at 47-48. For another contemporary version of the "futility" thesis, see Gerald N. Rosenberg, The Hollow Hope: Can Courts Bring About Social Change? (U. of Chi. Press, 1991).

95. Any calls for judicial civil disobedience must come to terms with the fact that abolitionist judges yielded to unjust positive laws supporting slavery. See Robert Cover, Justice Accused: Antislavery and the Judicial Process (Yale U. Press, 1975); Ronald Dworkin, The Law of the Slave-Catchers, Times (London) Literary Supplement, Dec. 5, 1975, at 1437 (reviewing Cover, supra). See also Barber, On What the Constitution Means 199-202 (cited in note 75); Christopher L. Eisgruber, Dred Again: Originalism's Forgotten Past, 10 Const. Comm. 37 (1993); Christopher L. Eisgruber, Note, Justice Story, Slavery, and the Natural Law Foundations of American Constitutionalism, 55 U. Chi. L. Rev. 273 (1988). 
in United States $\nu$. Nixon, 96 President Richard Nixon did turn over those tapes. 97

To Ackerman's dualist claims about the absurdity or preposterousness of judicial review of morally disastrous amendments, and to fears about its futility, I offer three responses. The first is to repeat what Hart said concerning such situations: "Here all that succeeds is success."98 The second is to imagine what Yogi Berra, paraphrasing Hart, might have said: "Here nothing succeeds like failure." By that paradoxical utterance, I mean to suggest the possibility that judicial review (or judicial civil disobedience) invalidating repeals of liberty of conscience and freedom of speech-whether successful or futile in a narrow legal sense-would succeed in dramatically signaling that a constitutional breakdown or revolution was occurring.99

My final response is to admit that-from a larger perspective outside our constitutional enterprise-constitutions, constitutional interpretation, and judicial review are themselves preposterous and absurd. As William F. Harris expresses it: "American constitutional interpretation takes for granted the elemental preposterousness of its subject-the presumption that a political world can be constructed and controlled with words." 100 And, in the face of a determined political will, constitutionswritten or unwritten, with or without entrenchment clausesmay be "absurd attempts, on the part of the people, to limit a power in its own nature illimitable."101 We should not, however, adopt such an external point of view in assessing the foundations of legitimacy in our constitutional order. ${ }^{102}$ Our Constitution is

96. 418 U.S. 683 (1974).

97. See John Hart Ely, War and Responsibility: Constitutional Lessons of Vietnam and Its Aftermath 56 (Princeton U. Press, 1993). Ely also states: "That the president will disobey an order of the Supreme Court seems less likely in 1993 than it might have 100 years ago." Id. Our long and moderately successful constitutional tradition and practice are what makes it seem less likely today. See supra text accompanying note 69.

98. Hart, The Concept of Law at 149 (cited in note 18).

99. Cf. Ackerman, We the People at $272-80$ (cited in note 2) (discussing signaling concerning higher lawmaking in constitutional moments).

100. Harris, The Interpretable Constitution at 1 (cited in note 17). Harris explains that he means the word "preposterousness" in "both its original and derived senses: (a) inverted in time, the 'later' coming before, and the 'before' coming later, and (b) 'contrary to nature, reason, or common sense." "Id. at 1 n.1.

101. Cf. Marbury v. Madison, 5 U.S. (1 Cranch) 137, 177 (1803) (discussed supra text accompanying note 24 ).

102. I mean to echo Hart's notion of an "external" versus an "internal" point of view toward a legal system. See, e.g., Hart, The Concept of Law 86-88, 99-100, 112, 114 (cited in note 18). 
underwritten by more than the fact of political power lying under an imperfect dualist Constitution. 103

\section{WE THE EXCEPTIONAL AMERICAN PEOPLE?}

The bicentennial celebration of the ratification of the Bill of Rights is over. James Madison rightly proclaimed in The Federalist No. 14: "[The People of America] reared the fabrics of governments which have no model on the face of the globe."104 Two centuries later, though, these fabrics of governments have served as models for other countries (and will continue to do so if efforts like Ackerman's project of American imperialism, or exporting liberal revolution to the countries of Eastern Europe, make any headway). ${ }^{105}$ Ironically, the upshot of Ackerman's project of "American exceptionalism" is that on his view We the People, the American popular sovereign, are ultimately quite similar to the "legally untrammelled will" of the sovereign that is envisioned in British legal positivism and that positivist dualists would find standing behind the entrenchment clauses of the purportedly rights foundationalist German Basic Law.106 The American constitutional order may well be exceptional, but Ackerman has not established his case for dualism over rights foundationalism as the better account of the American scheme of government through his contrast between the American Constitution and the German Basic Law.

103. See supra text accompanying notes $25-27$.

104. The Federalist No. 14 at 104 (James Madison) (cited in note 1).

105. See Ackerman, The Future of Liberal Revolution (cited in note 5). Ackerman also considers "the meaning of 1989" and the revolutions of Eastern Europe for South Africa and Latin America, not to mention the United States. Id. at 113-23.

106. See supra text accompanying notes 18-27. 